\title{
DOXORUBICIN AND ETOPOSIDE INDUCE SOMATIC RECOMBINATION IN DIPLOID CELLS OF ASPERGILLUS NIDULANS
}

\author{
Simone Jurema Ruggeri Chiuchetta, Marialba Avezum Alves de Castro-Prado \\ Departamento de Biologia Celular e Genética, Universidade Estadual de Maringá, Maringá, Paraná, Brasil.
}

Submitted: May 27, 2002; Approved: September 24, 2002

\begin{abstract}
Doxorubicin and etoposide are intercalating agents that inhibit the action of the enzyme topoisomerase II. Both drugs present therapeutic activity in numerous human neoplasms In the present work the recombinagenic potential of these drugs was evaluated by ascomycete Aspergillus nidulans. Their effects on the asexual cycle of A. nidulans was also appraised. Two heterozygous diploid strains of $A$. nidulans, a wild (uvsH+// $u v s H+)$ and a defective to the DNA repair (uvsH//uvsH) were used. The drugs' recombinagenic potential was evaluated by their capacity to induce homozygosis of recessive genes from heterozygous cells. Both drugs have a recombinagenic effect on diploid cells of $A$. nidulans. Doxorubicin and etoposide are potentially capable to induce secondary malignancies, mediated by the mitotic crossing-over in eukaryotic cells.
\end{abstract}

Key words: antineoplastic agents, mitotic crossing-over, secondary malignances

\section{INTRODUTION}

Doxorubicin and etoposide are antineoplastic drugs classified as intercalating agents, a cytotoxic group of drugs that, bound to DNA, inhibits the action of topoisomerase II (11).

Doxorubicin is an anthracycline antibiotic produced by fungus Streptomyces peucelius var. caesius; etoposide is a semisynthetic glycoside from podophyllotoxin, an active compound extracted from the Podophyllum pittatum plant. Both drugs present therapeutic activity in numerous human neoplasms such as breast cancer, ovary carcinoma, head and neck carcinoma, leukemia, lung carcinoma, and testicle tumors (5).

Studies on human fibroblasts demonstrated that the two intercalating agents, doxorubicin and etoposide, block the $\mathrm{S}$ phase of the cellular cycle after a short period of cell treatment (15). An induction of breaks in DNA double-strands by doxorubicin and etoposide was also reported in leukemia cells after $3 \mathrm{hrs}$ of exposition to the chemotherapic agents (8).

Chromosomic breaks and high frequencies of somatic recombination have been observed in cells of Bloom's syndrome or Fanconi anemia patients whose present predisposition to cancer development. Due to an exchange of segments between homologous chromatids, the somatic recombination seems to be associated with the high cancer incidence reported in these diseases $(7,9,17)$.

Two chromosomic events are involved in the development of neoplasms: i) a genetic or epigenetic alteration that results in a pre-malignant heterozygous condition $(\mathrm{m} /+)$ and ii) a chromosomic rearrangement involving the affected locus, which results in homozygosis $(\mathrm{m} / \mathrm{m})$ or hemizygosis $(\mathrm{m} / 0)$, with the subsequent expression of the recessive malign character. Homozygous cells $(\mathrm{m} / \mathrm{m})$ may originate from the exchange of segments between homologous chromatids, in the G2 phase of the cellular cycle, proceeded by the segregation of recombinant chromatids to opposite mitotic poles $(3,14)$.

The ascomycete Aspergillus nidulans is an excellent system for the study of mitotic crossing-over. This is due to the fact that its cells pass a substantial part of their cellular cycle in the G2 phase during germination. At this phase, the existence of two copies of each chromosome benefits mitotic recombination events (12).

Our research aimed at investigating the roles of doxorubicin and etoposide in the homologous interchromosomal recombination in heterozygous cells of $A$. nidulans. Two diploid strains were used, a defective to DNA repair and a normal one.

\footnotetext{
* Corresponding author. Mailing address: Universidade Estadual de Maringá, Departamento de Biologia Celular e Genética. Av. Colombo, 5790. 87020-900, Maringá, PR, Brasil. Tel.: (+5544) 261-4679. E-mail: maacprado@uem.br
} 


\section{MATERIALS AND METHODS}

\section{Strains}

The A. nidulans strains were derived from Utrecht (UT448) and FGSC (A757, A737). The B211 strain was obtained in our laboratory (4). Diploid strains (UT448//A757 and B211//A837) were prepared according to Roper (16). Genotypes of the strains: a) UT448: riboA1, pabaA124, biA1, AcrA1, wA2; b) A757: yA2, methA17, pyroA4; c) A837: pabaA1, uvsH77, pyroA4, choA1, chaA1; d) B211: $y A 2$, biA1, AcrA1, wA2, methA17, uvsH77, pyro A4, chaAl.

\section{Culture media}

Complete medium (CM) and minimum medium (MM) were prepared as described by Van de Vate and Jansen (19). The selective medium (SM) was prepared with MM supplemented with the nutritional requirements for each strain. Solid medium was prepared with $1.5 \%$ agar and strain growth was incubated at $37^{\circ} \mathrm{C}$.

\section{Doxorubicin and etoposide treatment}

Doxorubicin (ICN), dissolved in an aqueous solution, and etoposide (ICN), dissolved in 10 $\mu$ LMSO, were added to molten MM. Solvent was per se neither visibly toxic nor recombinagenic for the diploid strain (results not shown). Doxorubicin concentration that induced breaks in DNA strand in leukemia cells at $2.0 \mu \mathrm{g} / \mathrm{ml}(8)$ and etoposide concentration with induced cell cycle arrested in normal fibroblast at $1.0 \mu \mathrm{g} / \mathrm{ml}$ (15) and at higher concentrations $(4.0 \mu \mathrm{g} / \mathrm{ml}$ doxorubicin and $3.0 \mu \mathrm{g} / \mathrm{ml}$ etoposide) were used in the present study. They were final in agar medium.

\section{Evaluation of the recombinagenic potential}

Conidia of each diploid strain were inoculated in $\mathrm{MM}+$ antineoplastic agents. Treatment produced visible diploid sectors, D1-D32, identified by their different morphology from the original diploid. Diploid sectors were submitted to spontaneous haploidization in CM after purification in MM. Only haploid segregants were selected for recombinagenesis test. Conidia of each haploid sector were transferred to 25 defined positions in CM plates (master plates). After 48 hours of incubation at $37^{\circ} \mathrm{C}$, colonies were transferred to $\mathrm{SM}$ and the phenotypical analysis of the haploid segregants was carried out.

The treatment with the drugs in MM will produce only heterozygous $(+/$ - or $-/+)$ or homozygous $(+/+)$ segregants because the recessive ones (-/-) fail to grow in MM. After haploidization of diploids D1-D32 the nutritional markers will segregate among the haploids in the proportion of 4+: 4-, if drug fails to induce recombinagenesis; or 4+: 2-, if drug induces crossing-over. Values of Homozigotization Indexes (HI) (the ratio between number of phototropic and auxotrophic segregants) equal or above 2.0 evidence the recombinagenic effects of the substance under analysis $(2,13)$. Results were compared by Yates correct Chi-Square test.

\section{Cytological analysis}

Colonies of UT448//A757 diploid were cultivated in dialysis membranes aseptically placed on the surface of plates containing CM and CM + doxorubicin or etoposide. Samples were collected after $8,12,18$ and 24 hours of incubation at $37^{\circ} \mathrm{C}$. Membranes were stained with lactophenol cotton blue and examined under an optic microscope.

\section{RESULTS}

The mycelial growth of UT448//A757 and B211//A837 diploid strains cultivated in $\mathrm{MC}+$ doxorubicin $(2.0$ and $4.0 \mu \mathrm{g} / \mathrm{ml})$ and etoposide $(1.0$ and $3.0 \mu \mathrm{g} / \mathrm{ml}$ ) was normal when compared with that of controls (results not shown). On the other hand, alterations in the morphology of the conidiophores were observed in the cytological preparations of the UT448//A757 diploid, cultivated in the presence of the two antineoplastic agents. Conidiophore is formed by an aerial hypha, a multinucleated vesicle and two tiers of uninucleate cells (metulae and phialides) forming the sterigmata (18). Vacuoles in the stalk and in the conidiophore's vesicle were observed in preparations with $2.0 \mu \mathrm{g} / \mathrm{ml}$ and $1.0 \mu \mathrm{g} /$ $\mathrm{ml}$ of doxorubicin and etoposide respectively (data not given). Conidiophores with shortened and malformed stalks were observed in higher doses of each drug $(4.0 \mu \mathrm{g} / \mathrm{ml}$ of doxorubicin and $3.0 \mu \mathrm{g} / \mathrm{ml}$ of etoposide) (Fig. 1).

Methodology does not permit the isolation of auxotrophic diploids (-/-) since they are not selected in MM. However, homozygous recessive diploids may be obtained for conidia coloration markers $(y, w$ and $c h a)$. The treatment of B211//A837 diploid strain with both drugs merely allowed the isolation of prototrophic diploids with chartreuse (cha//cha) conidia. Contrastingly the treatment with doxorubicin of UT448//A757 diploid originated prototrophic diploids with green $(y+/ / y)$ and yellow $(y / / y)$ conidia. Through the phenotypical analyses of D8 (yellow) it was possible to determine that it is recombinant for the centromere-paba interval. The diploid D8 showed HI value higher than 2.0 for the meth marker (Table 1).

Most diploids from UT448//A757 strain exhibited HIs <2.0 for doxorubicin and etoposide. HI value of only one diploid was higher than 2.0 for doxorubicin $(2.0 \mu \mathrm{g} / \mathrm{ml})$ and etoposide $(1.0 \mu \mathrm{g} / \mathrm{ml})$, and the markers involved were meth and $b i$ respectively. In higher concentrations the recombinagenic effect was reported in markers paba and meth for doxorubicin, and in paba and $b i$ for etoposide (Tables 1 and 2).

Diploids from B211//A837 strain exhibited the highest sensitivity for antineoplasics. This fact was confirmed from high values of $\mathrm{HI}$ obtained in the recombinagenic test. For both doses of each drug, the markers involved in the recombinagenic effect were paba and bi (Tables 3 and 4). Analyses also determined 

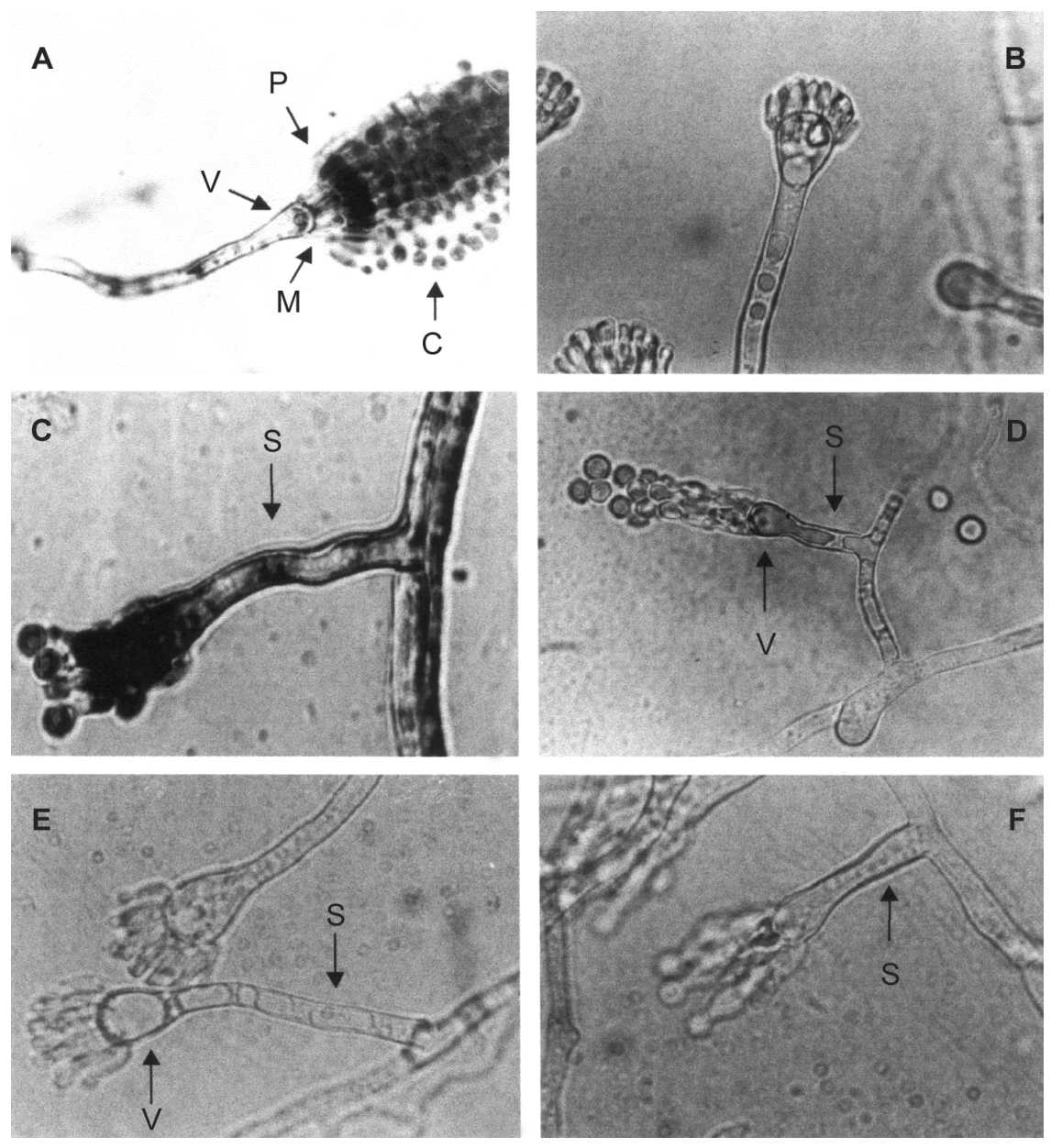

Figure 1. Growth of the conidiophore UT448//A757 in MC and in MC + antineoplastics agents. A) normal conidiophore; B) presence of vacuole in the conidiophore's vesicle (doxorubicin $4.0 \mu \mathrm{g} / \mathrm{ml}$ ); C) shortened and malformed conidiophore stalk (doxorubicin $4.0 \mu \mathrm{g} / \mathrm{ml}$ ); D) presence of vacuole in the vesicle and shortened conidiophore stalk (doxorubicin $4.0 \mu \mathrm{g} / \mathrm{ml}$ ); E) presence of vacuole in the vesicle and in the conidiophore

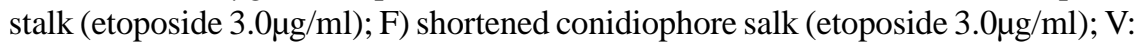
vesicle; M: metulae; P: phialides; C: conidium; S: conidiophore stalk. Diameter of the conidiophore's vesicle corresponds to $10 \mu \mathrm{m}$. that diploids from B211//A837 strain produced a high number of haploid mitotic segregants in MC.

\section{DISCUSSION}

Alterations in DNA caused by chemical substances may act as starters in a complex carcinogenesis process. The loss of heterozygosity in normal cells, which carry mutations in malignant genes, by mitotic recombination, may unchain a neoplasic process (14).

In Fanconi's anemia and in Bloom's syndrome, cells of affected individuals present an enhanced level of chromosome breakage, somatic recombination and an increase in neoplastic incidence. The risk of developing tumors in these individuals is nearly 15,000 -fold greater than that of the general population. The loss of heterozygosity in specific genes through the recombination mechanism in somatic cells may explain the increase of this incidence. It even corroborates the hypothesis that cancer may be a recessive disease at cell level $(7,9,17)$.

Mycelial growth of UT448//A757 and B211//A837 diploids in the presence of doxorubicin and etoposide was similar to that of controls (results not shown). Results indicate that doses of the antineoplastic agents used in current research do not provide any toxicity to the organism under analysis, although alterations in the structure of the conidiophore (asexual cycle) were microscopically observed (Figure 1).

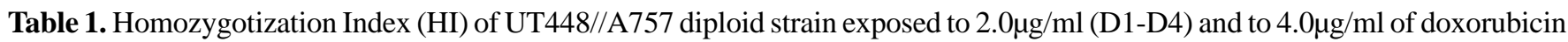
(D1-D8). $\mathrm{n}^{\mathrm{o}}$ seg.; number of haploid mitotic segregants. C., control.

\begin{tabular}{|c|c|c|c|c|c|c|c|c|c|c|c|c|c|c|c|c|c|c|}
\hline & \multicolumn{2}{|l|}{ C } & \multicolumn{2}{|c|}{ D1 } & \multicolumn{2}{|c|}{ D2 } & \multicolumn{2}{|c|}{ D3 } & \multicolumn{2}{|c|}{ D4 } & \multicolumn{2}{|c|}{ D5 } & \multicolumn{2}{|c|}{ D6 } & \multicolumn{2}{|c|}{ D7 } & \multicolumn{2}{|c|}{ D8 } \\
\hline & $\mathrm{n}^{\circ} \mathrm{seg}$. & HI & $\mathrm{n}^{\mathrm{o}} \mathrm{seg}$. & $\mathrm{HI}$ & $\mathrm{n}^{\mathrm{o}}$ seg. & $\mathrm{HI}$ & $\mathrm{n}^{\mathrm{o}}$ seg. & $\mathrm{HI}$ & $\mathrm{n}^{\mathbf{o}} \mathrm{seg}$ & $\mathrm{HI}$ & $\mathrm{n}^{\mathrm{o}} \mathrm{seg}$. & $\mathrm{HI}$ & $\mathrm{n}^{\mathrm{o}} \mathrm{seg}$ & $\mathrm{HI}$ & $\mathrm{n}^{0} \mathrm{seg}$ & $\mathrm{HI}$ & $\mathrm{n}^{0}$ seg & . HI \\
\hline paba+ & 37 & 1.15 & 39 & 1.50 & 45 & 1.55 & 40 & 1.82 & 54 & 1.92 & 42 & 1.62 & 47 & 1.88 & 45 & $* 2.14$ & 72 & 0 \\
\hline paba- & 32 & & 26 & & 29 & & 22 & & 28 & & 26 & & 25 & & 21 & & 0 & \\
\hline$b i+$ & 40 & 1.37 & 36 & 1.24 & 41 & 1.24 & 37 & 1.48 & 52 & 1.73 & 41 & 1.52 & 42 & 1.40 & 42 & 1.75 & 72 & 0 \\
\hline$b i-$ & 29 & & 29 & & 33 & & 25 & & 30 & & 27 & & 30 & & 24 & & 0 & \\
\hline meth + & 38 & 1.22 & 41 & 1.70 & 49 & 1.96 & 39 & 1.69 & 56 & $* 2.15$ & 41 & 1.52 & 43 & 1.48 & 40 & 1.53 & 49 & $* 2.13$ \\
\hline meth- & 31 & & 24 & & 25 & & 23 & & 26 & & 27 & & 29 & & 26 & & 23 & \\
\hline
\end{tabular}

* Significantly different from control, $\mathrm{P}<0.05$ (Yates correct Chi-square test, Statistic for Windows Program). 


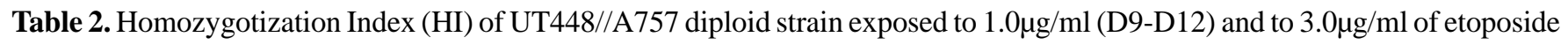
(D13-D16). $\mathrm{n}^{\mathrm{o}}$ seg.; number of haploid mitotic segregants. C., control.

\begin{tabular}{|c|c|c|c|c|c|c|c|c|c|c|c|c|c|c|c|c|c|c|}
\hline & \multicolumn{2}{|l|}{$\mathrm{C}$} & \multicolumn{2}{|c|}{ D9 } & \multicolumn{2}{|c|}{ D10 } & \multicolumn{2}{|c|}{ D11 } & \multicolumn{2}{|c|}{$\bar{D} 12$} & \multicolumn{2}{|c|}{ D13 } & \multicolumn{2}{|c|}{ D14 } & \multicolumn{2}{|c|}{ D15 } & \multicolumn{2}{|c|}{ D16 } \\
\hline & $\mathrm{n}^{\mathrm{o}} \mathrm{seg}$. & $\mathrm{HI}$ & $\mathrm{n}^{\mathrm{o}} \mathrm{seg}$. & $\mathrm{HI}$ & $\mathrm{n}^{\mathrm{o}} \mathrm{seg}$ & HI & $\mathrm{n}^{0} \mathrm{seg}$. & $\mathrm{HI}$ & $\mathrm{n}^{\mathrm{o}} \mathrm{seg}$. & $\mathrm{HI}$ & $\mathrm{n}^{0} \mathrm{seg}$ & $\mathrm{HI}$ & $\mathrm{n}^{\mathrm{o}} \mathrm{seg}$ & $\mathrm{HI}$ & $\mathrm{n}^{\mathrm{o}} \mathrm{seg}$ & $\mathrm{HI}$ & $\mathrm{n}^{0} \mathrm{seg}$ & 5I \\
\hline$p a b a+$ & 37 & 1.15 & 43 & 1.72 & 37 & 1.85 & 35 & 1.40 & 47 & 1.80 & 42 & *2.33 & 40 & 1.90 & 44 & 1.57 & 35 & 1.66 \\
\hline paba- & 32 & & 25 & & 20 & & 25 & & 26 & & 18 & & 21 & & 28 & & 21 & \\
\hline$b i+$ & 40 & 1.37 & 46 & *2.09 & 32 & 1.28 & 39 & 1.85 & 46 & 1.70 & 34 & 1.30 & 31 & 1.03 & 42 & 1.40 & 39 & $* 2.29$ \\
\hline$b i-$ & 29 & & 22 & & 25 & & 21 & & 27 & & 26 & & 30 & & 30 & & 17 & \\
\hline meth + & 38 & 1.22 & 44 & 1.83 & 33 & 1.37 & 38 & 1.72 & 43 & 1.43 & 35 & 1.40 & 39 & 1.77 & 46 & 1.76 & 34 & 1.54 \\
\hline meth- & 31 & & 24 & & 24 & & 22 & & 30 & & 25 & & 22 & & 26 & & 22 & \\
\hline
\end{tabular}

* Significantly different from control, $\mathrm{P}<0.05$ (Yates correct Chi-square test, Statistic for Windows Program).

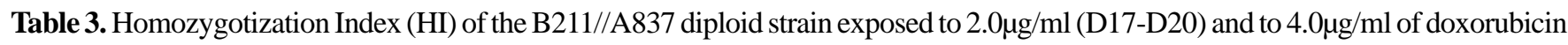
(D21-D24). $\mathrm{n}^{\mathrm{o}}$ seg.; number of haploid mitotic segregants. C., control.

\begin{tabular}{|c|c|c|c|c|c|c|c|c|c|c|c|c|c|c|c|c|c|}
\hline & \multicolumn{2}{|l|}{$\mathrm{C}$} & \multicolumn{2}{|c|}{ D17 } & \multicolumn{2}{|c|}{ D18 } & \multicolumn{2}{|c|}{ D19 } & \multicolumn{2}{|c|}{ D20 } & \multicolumn{2}{|c|}{ D21 } & \multicolumn{2}{|c|}{$\mathrm{D} 22$} & \multicolumn{2}{|c|}{$\mathrm{D} 23$} & D24 \\
\hline & $\mathrm{n}^{\circ}$ seg. & HI & $\mathrm{n}^{0}$ seg. & $\mathrm{HI}$ & $n^{\circ}$ seg. & HI & $\mathrm{n}^{0}$ seg. & $\mathrm{HI}$ & $\mathrm{n}^{\circ}$ seg. & $\mathrm{HI}$ & $\mathrm{n}^{0}$ seg. & $\mathrm{HI}$ & $\mathrm{n}^{\mathrm{o}}$ seg. & HI & $\mathrm{n}^{0} \mathrm{seg}$. & $\mathrm{HI}$ & $\mathrm{n}^{0}$ seg. HI \\
\hline$p a b a+$ & 73 & 1.97 & 78 & 2.51 & 64 & 1.82 & 82 & $* 3.15$ & 61 & 1.52 & 65 & 1.85 & 62 & 1.93 & 76 & $* 4.00$ & $66 \quad 1.69$ \\
\hline paba- & 37 & & 31 & & 35 & & 26 & & 40 & & 35 & & 32 & & 19 & & 39 \\
\hline$h i+$ & 70 & 1.75 & 67 & 1.59 & 76 & *3.30 & 68 & 1.70 & 57 & 1.29 & 61 & 1.56 & 67 & $* 2.48$ & 62 & 1.87 & $80 * 3.20$ \\
\hline hi & 40 & & 42 & & 23 & & 40 & & 44 & & 39 & & 27 & & 33 & & 25 \\
\hline meth+ & 72 & 1.89 & 45 & 0.70 & 52 & 1.10 & 56 & 1.07 & 45 & 0.80 & 30 & 0.42 & 39 & 0.70 & 42 & 0.79 & $\begin{array}{ll}48 & 0.84\end{array}$ \\
\hline meth- & 38 & & 64 & & 47 & & 52 & & 56 & & 70 & & 55 & & 53 & & 57 \\
\hline
\end{tabular}

* Significantly different from control, $\mathrm{P}<0.05$ (Yates correct Chi-square test, Statistic for Windows Program).

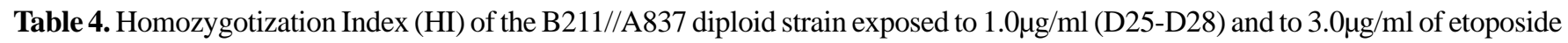
(D29-D32). nº seg.; number of haploid mitotic segregants. C., control.

\begin{tabular}{|c|c|c|c|c|c|c|c|c|c|c|c|c|c|c|c|c|c|c|}
\hline & \multicolumn{2}{|c|}{$\mathrm{C}$} & \multicolumn{2}{|c|}{ D17 } & \multicolumn{2}{|c|}{ D18 } & \multicolumn{2}{|c|}{ D19 } & \multicolumn{2}{|c|}{ D20 } & \multicolumn{2}{|c|}{ D21 } & \multicolumn{2}{|c|}{ D22 } & \multicolumn{2}{|c|}{ D23 } & \multicolumn{2}{|c|}{ D24 } \\
\hline & seg. & HI & $\mathrm{n}^{\mathrm{o}}$ seg. & HI & $\mathrm{n}^{\mathrm{o}} \mathrm{seg}$. & $\mathrm{HI}$ & $\mathrm{n}^{\mathrm{o}} \mathrm{seg}$. & $\mathrm{HI}$ & $\mathrm{n}^{\circ}$ seg. & $\mathrm{HI} \quad 1$ & $\mathrm{n}^{\mathrm{o}} \mathrm{seg}$. & $\mathrm{HI}$ & $\mathrm{n}^{\mathrm{o}}$ seg. & $\mathrm{HI}$ & $\mathrm{n}^{\mathrm{o}} \mathrm{seg}$ & $\mathrm{HI} \quad 1$ & $\mathrm{n}^{\mathrm{o}} \mathrm{seg}$. & 5. HI \\
\hline$p$ & 73 & 1.97 & 76 & *3.04 & 69 & 1.72 & 75 & 2.14 & 82 & *3.56 & 81 & *3.68 & 65 & 1.75 & 78 & *3.90 & 88 & $* 4.00$ \\
\hline$p a b a-$ & 37 & & 25 & & 40 & & 35 & & 23 & & 22 & & 37 & & 20 & & 22 & \\
\hline$b i+$ & 70 & 1.75 & 65 & 1.80 & 72 & 1.94 & $83 *$ & *3.07 & 69 & 1.91 & 67 & 1.86 & 67 & 1.91 & 64 & 1.88 & 85 & $* 3.40$ \\
\hline$b i-$ & 40 & & 36 & & 37 & & 27 & & 36 & & 36 & & 35 & & 34 & & 25 & \\
\hline eth+ & 72 & 1.89 & 49 & 0.94 & 57 & 1.09 & 53 & 0.92 & 57 & 1.18 & 50 & 0.94 & 54 & 1.12 & 48 & 0.96 & 58 & 1.11 \\
\hline meth- & 38 & & 52 & & 52 & & 57 & & 48 & & 53 & & 48 & & 50 & & 52 & \\
\hline
\end{tabular}

* Significantly different from control, $\mathrm{P}<0.05$ (Yates correct Chi-square test, Statistic for Windows Program).

Concerning the recombinagenic potential, results obtained indicate that doxorubicin and etoposide were also capable of inducing homozygosis. These observations were based on the high Homozigotization Indexes values (HI > 2.0) obtained for diploids treated with the two drugs (Tables 1-4).

The fact that diploids derived from B211//A837 strain showed $\mathrm{HI}$ values higher than those derived from UT448//A757 one is due to the uvs mutation in their genome. Homozygous diploid strains for $u v s H$ mutation cause an efficient increase in the mitotic crossing-over frequency and in chromosome instability (10).
The loss of a functional copy of a heterozygous tumor suppressor gene represents an important step during neoplasic transformation. (1). Treatment with an anticancer drug causing mitotic crossing-over might lead to the expression of recessive genes, previously masked in a heterozygous condition. The clinical use of these drugs might increase cancer risk (6). Our results demonstrate the carcinogenic potential of doxorubicin and etoposide antineoplastics through heterozygosity loss. They are potentially capable of inducing secondary malignancies by the mitotic crossing-over. 


\section{RESUMO}

\section{Doxorubicina e etoposida induzem a recombinação somática em células diplóides de Aspergillus nidulans}

Doxorubicina e etoposida são agentes intercalantes que inibem a ação da enzima topoisomerase II. Ambas drogas são amplamente utilizadas no tratamento de neoplasias. O potencial recombinagênico destes agentes e seus efeitos sobre o ciclo assexual de Aspergillus nidulans foram avaliados no presente trabalho. Duas linhagens diplóides heterozigotas foram utilizadas: uma selvagem ( $u v s H+/ / u v s H+)$ e outra deficiente para o reparo do DNA (uvsH//uvsH). O potencial recombinagênico destas drogas foi avaliado pela indução de homozigose de genes recessivos a partir de células heterozigotas. Doxorubicina e etoposida apresentaram efeitos recombinagênicos em ambas linhagens utilizadas. Os resultados permitem concluir que doxorubicina e etoposida são agentes potencialmente capazes de induzir malignidades secundárias, mediadas pelo crossingover mitótico, em células diplóides eucariotas.

Palavras-chave: agentes antineoplásicos, crossing-over mitótico, malignidade secundária.

\section{REFERENCES}

1. Acuma, G.; Wurgler, F.E.; Sengstag, C. Reciprocal mitotic recombination is the predominant mechanism for the loss of a heterozygous gene in Saccharomyces cerevisiae. Environ Mol Mutagen., 24(4): 307-316, 1994.

2. Baptista, F.; Castro-Prado, M.A.A. Benlate-induced homozygosis from heterozygous diploids strain in Aspergillus nidulans. Cytologia, 62: 389-396, 1997.

3. Beumer, K.J.; Pimpinelli, S.; Golic, K.G. Induced chromosoma exchange directs the segregation of recombinant chromatids in mitosis of Drosophila. Genetics, 150: 173-188, 1998.

4. Busso, C.; Chiuchetta, S.J.R.; Baptista, F.; Castro-Prado, M.A.A $u v s H / / u v s H$ diploid strain favors an efficient method to evaluate the recombinagenic effect of chemical and physical agents in Aspergillus nidulans (Ascomycetes). Acta Scientiarium, 23(2): 603-607, 2001.
5. Chabner, B.A.; Allegra, C.J.; Curt, G.A.; Calabresi, P. Antineoplastic agents. In: Molinoff P.B. and Ruddon R.W. eds. The pharmacological basis of therapeutics. (9 ed.). New York: Mc Graw-Hill, 1233$1287,1996$.

6. Ferguson, L.R.; Turner, P.M. Mitotic crossing-over by anticancer drugs in Saccharomyces cerevisae strain D5. Mutat Res., 204: 239249, 1988

7. Festa, R.S.; Meadows, A.T.; Boshes, R.A. Leukemia in a black child with Bloom's syndrome : somatic recombination as a possible mechanism for neoplasia. Cancer, 44: 1507-1510, 1979.

8. Froelich, J.J.; Schneller, F.R.; Zahn, R.K. The influence of radiation and chemotherapy-related DNA strand breaks on carcinogenesis: an evaluation. Clin Chem Lab Med., 37: 403-408, 1999.

9. Hickson, I.D.; Davies, S.L.; Li, J.L.; Levitt, N.C.; Mohaghegh, P.; North, P.S.; Wu, L. Role of the Bloom's syndrome helicase in maintenance of genome stability. Biochem Soc Trans., 29: 201-204, 2001.

10. Iwanejko, L.; Cotton, C.; Jones, G.; Tomsett, B.; Strike, P. nuvA, an Aspergillus nidulans gene involved in DNA repair and recombination, is a homologue of Saccharomyces cerevisiae RAD18 and Neurospora crassa uvs-2. Microbiology, 142: 505-515, 1996.

11. Noviello, E.; Aluigi, M.G.; Cimoli, G.; Rovini, E.; Mazzoni, A.; Parodi, S.; Sessa, F.; Russo, P. Sister-chromatid exchanges, chromosomal aberrations and cytotoxicity produced by topoisomerase II-targed drugs in sensitive (A2780) and resistant (A2780-DX3) human ovarian cancer cells: correlations with the formation of DNA doublé-strand breaks. Mut Res., 311: 21-29, 1994.

12. Osman, F.; Tomsett, B.; Strike, P. The isolation of mutagen-sensitive nuv mutants of Aspergillus nidulans and their effects on mitotic recombination. Genet., 134: 445-454, 1993.

13. Pires, L.T.A.; Zucchi, T.M.A.D. A new method to detect potential genotoxic agents using mitotic crossing over in diploid strains of Aspergillus nidulans. Braz. J. Genet., 17: 371-376, 1994.

14. Radman, M.; Kinsella, A.R. Chromosomal events in carcinogenic initiation and promotion : implication for carcinogenicity testing and cancer prevention strategies. IARC Sci. Publ., 27: 75-90, 1980.

15. Robles, S.J.; Burchler, P.W.; Negruz, A.; Adami, G.R. Permanent cel cycle arrest in asynchronously proliferating normal human fibroblasts treated with doxorrubicin or etoposide but not camptothecin Biochem. Pharm., 58: 675-685, 1999.

16. Roper, J.A. Production of heterozygous in filamentous fungi. Experientia, 8: 14-15, 1952

17. Thyagarajan, B.; Campbell, C. Elevated homologous recombination activity in Fanconi anemia fibroblasts. J. Biol. Chem., 272: 23328 23333, 1997.

18. Timberlake, W.E. Molecular genetics of Aspergillus development. Апnи. Rev. Genet., 24: 5-36, 1990.

19. Van de Vate, C.; Jansen, G.J.O. Meiotic recombination in a duplication strain of Aspergillus nidulans. Gen Res., 31: 29-52, 1978. 